\title{
The Politics of Opposition in Post - 2005 Ethiopia: Challenges and Prospects in the Case of National Political Parties
}

\author{
Simeneh Bires Belete \\ Department of Civics and Ethical Studies, College of Social Science and Humanities, Dambi Dollo University, Dambi Dollo Town, Ethiopia \\ Email address: \\ semenehbiresaw@gmail.com

\section{To cite this article:} \\ Simeneh Bires Belete. The Politics of Opposition in Post - 2005 Ethiopia: Challenges and Prospects in the Case of National Political Parties. \\ International and Public Affairs. Vol. 5, No. 1, 2021, pp. 29-39. doi: 10.11648/j.ipa.20210501.16
}

Received: February 2, 2021; Accepted: March 29, 2021; Published: April 29, 2021

\begin{abstract}
The paper examines the Politics of Opposition in post - 2005 Ethiopia: Challenges and prospects in the case of national opposition political parties. 2005 is selected because opposition parties were able to secure more votes than ever before in this election. To address the objectives of the study, the researcher employed qualitative approach with case study design and used primary and secondary data sources. The primary data was collected through semi-structured interviews and secondary sources such as books newspapers, other scholars' works and different documents also used. The data collected from the primary and secondary data sources were discussed and analyzed thematically based on the emerged themes from participants response. Hence, this case study aimed to explore the experience of these parties in the politics of opposition by focusing on challenges, and prospects in post- 2005 National elections. National parties were selected purposefully since they were active in Ethiopian politics of opposition in the country. Political parties exhibited weakness internally and faced challenges externally. But most opposition parties externalize their overall weakness. This has its impacts on Ethiopian politics of opposition and political process of the country. The study found that opposition parties do have internal and external challenges which affect their activities and do have impacts on political process of the country. Parties are less institutionalized, fragmented, absence of membership commitment and parties' leaders' time limit. They also faced challenges from the incumbent party, media and from other institutions of the country. Given research gaps in the domain, this study will help to improve the political culture, democratic system and politics of opposition of the country.
\end{abstract}

Keywords: National Political Parties, Politics of Opposition, Challenges and Prospects

\section{Introduction}

Politics of opposition is impossible without competitive political parties. The relevance of political parties in the organization of modern politics and governance is not a recent phenomenon [1]. According to Wondwosen Teshome B. and Jan Záhoík [2], political parties are crucial actors in bringing together diverse interests, recruiting and presenting candidates, and developing competing policy proposals that provide people with a choice. Political parties have also a role of representation function. In modern liberal democratic theory the electorate votes for people to represent them [1]. Political parties are pre-eminent institutions of modern democratic governance. The general consensus in comparative political thought and among policy makers is that political parties play a central role in deepening and fostering democracy in both established as well as emerging democratic politics Cowen and [3].

Modern political parties however exhibit three distinct characteristics lacking in Burke's definition. First, they have become more organized and centralized institutions with bureaucratic structures, secretariats and paid staffers. Secondly, modern parties do not necessarily work towards a national interest, but any kind of interest including regional, ethnic, racial, religious or economic objectives. Third, political parties are largely organized with the sole objective of competing for and capturing political office [4]. According to [5] the nature, forms and functions of political parties have continued to evolve in response to socio-economic and political changes in society. African political parties are 
products of distinct historical, socio-economic and political conditions that influence their character and functioning different from those prevailing in western democracies [6]. Unlike the majority of their western counterparts almost all African nation states lack in distinctive cultural or ethnolinguistic homogeneity [7]. They are highly heterogeneous along ethnic, regional, religious or clan cleavages.

The paradox of the majority of African political parties is that most of them are poorly organized and lack institutional capacity. However, opposition parties find themselves in crisis and increasingly distrusted. They are suffering from declining membership, internal management practices that are often weak and not sufficiently democratic and party system regulations that often set far reaching limits to the way in which parties are allowed to operate [8]. According to [9] during the reign of Haile Selassie there were no legitimate political parties in Ethiopia. Rather there are oppositions forces established along ethnic-based rebel fronts in the neighboring countries and waged guerilla warfare against the imperial government. They were supported by different countries. During the 'Derg's rule (1974-1991) all types of ethnic parties, multiethnic parties, and non-ethnic parties were persecuted [10]. There was only one party that was considered to be legal the Workers Party of Ethiopia (WPE). But armed struggle continued in the country against the 'Derge' in different parts of the country on the immediate aftermath of the coming to power of the 'Derg' [9]. It was through armed struggle that the insurgents took power and claiming Federal Democratic Republic of Ethiopia.

After the coming to power of the EPRDF in 1991 a number of ethnic-based political parties mushroomed in Ethiopia. The EPRDF, as an ethnic-based party coalition, encouraged the formation of political parties along ethnic lines and tacitly discouraged non-ethnic parties or other panEthiopian parties [2]. These political parties are criticized by different groups of writers, by the government or ruling party, by opposition groups themselves, or NGOs and some sections of the mass population. Still others have attitudes that reflect popular perceptions that the differences among political parties are more personal than programmatic [11]. The proclamation was issued after the formation of transitional government of Ethiopia [12]. Though legal parties are large in number they did not equally compute in election with the ruling party up to the 2005 Ethiopian election. The 2005 election results for the first time provided citizens with common knowledge about the local distribution of political preferences.

May 2005 national election and its aftermath clearly show the wider implications of the ensuing crisis in the country's political system. Following 2005 National election, different studies were done to assess problems of multiparty system and opposition in Ethiopia. For instance [13] studied that electoral administration (First past the post). Ethiopia is main challenging condition for multiparty democracy. [14] Tried to study on impacts of pre-election politics on multi party political competition. [15] Examined the nature of the May 2005 election of Ethiopia. At the same time [16] studied on the May 2005 electoral violence. Other reports such as Carter center [17] and other election observers forwarded that ruling party used voice buying and forces to suppress 2005 electoral violence. They did not describe the condition how political parties' internal and external challenges affect the political system, public political culture and post 2005 political environment. In this research the researcher wanted to study on gaps where and how opposition parties faced challenges, how do they cope up their activities with challenging conditions and its long term effects. This issue is either unstudied or scantly addressed. To clearly put politics of opposition in post 2005 Ethiopia exhaustive and empirical research is necessary. The existences of such unexplored issues along with the critical problem of internal and external challenges of opposition political parties in Ethiopia thus have demanded for the conduct of this study.

This research aimed to explore post 2005 Ethiopian politics of opposition, challenges, weakness and impacts.

\section{Research Methods}

In line with this Qualitative research approaches was used. Scholars like [18] stressed on the advantage of using qualitative approach in the study of social relation and political parties their challenges and impacts can help to attain the perspectives of the participants and their diversity. Hence the researcher employs a qualitative research design and the data be analyzed qualitatively. In qualitative one the aim is to go through case study. The researcher makes inferences based on objective and subjective analysis of different reports, recorded communications such as newspapers, books and seminars about the challenges and impact of legal opposition political parties in post 2005 Ethiopian election.

Case study is both method and tool for research [19]. The researcher chooses case study design because it helps to investigate politics of opposition in post 2005 Ethiopia, challenges and impacts of election. The researcher used reports of different individuals, groups, organizations or parties' comments on challenges and their impacts in post 2005 Ethiopian election with no direct interaction between the researcher and those of opposition political parties in Ethiopia.

\subsection{Selection of Participants}

In qualitative research, sampling can occur at several stages, both in collecting data, and while interpretive and reporting on it [20]. The researcher studied this research by taking purposive sampling design. Purposive sampling, one of the most common sampling strategies, groups participants according to preselected criteria relevant to study the Politics of Opposition in post -2005 Ethiopia: Challenges and Impacts on Ethiopian Democratic Party (EDP) and Blue Party. In purposive sampling (non - probability sampling) National legal opposition political parties' leaders (representatives) ruling party representatives and executives are parts of the study. In the sample there were 10 
interviewees. 2 were from EDP, 2 from Blue party, 1 from UDJ, 1 from AEUO, 2 from NEBE, 1 from EPRDF head office and 1 from AAU. Interview was taking from March20April 12, 2017.

\subsection{Data Collection Tools}

The researcher used both primary and secondary sources. But the researcher depended more of secondary sources. The researcher collected the data by using interview. To achieve the objectives of the study, both the primary and secondary sources of data were employed. Primary Sources: for this study, mainly used primary data sources because it gives first hand information. As far as the primary sources concerned semi-structured interviews was used.

\subsubsection{Primary Data Sources}

Interview: - The primary data was collected from party leaders, political experts and political activists by using semi structured interviews. An interview is a series of questions a researcher addresses personally to respondents. According to [21] qualitative interviewing is a kind of guided conversation in which there is careful listening so as to hear the meaning of what is being convey. Interview is the key technique and the most commonly used in qualitative research.

It allows the researcher to produce a rich, depth and varied data set in an informal setting. It provides through examinations of experiences, feelings or opinions that closed questions could never hope to capture there are many types of interview. But the researcher chooses key informant and in-depth interviews in the researcher's study. An interview may be structured or unstructured, where it allow the interviewer questioning to be led by the responses of the interviewee. In semi-structured interview (interview which use the predetermined categories of a responses), the researcher used a set of predetermined questions which are short and clearly worded. Such kind of interviewing is easy to conduct, and can be easily standardized as the same questions are asked to all participants. Primary data was collected from two groups of informants: politicians and party technocrats on the one hand, and experts and commentators on the other. The bulk of detailed party information on internal structures, decision-making processes and institutional set-up was obtained through semi a structured interview with selected political parties and party technocrats and/or politicians. The interview was aimed at getting inside information from respondents on specific aspects of intra-party democracy within their political parties. The data obtained was supplemented by follow-up face-toface interviews, telephone interview and through email with leading party officials and opposition party representatives or spokespersons.

\subsubsection{Secondary Sources}

Secondary Sources: The study employed secondary data source which includes published and unpublished documents. The researcher tried to use works of various authors and other published and unpublished documents such as books, articles, and journals were used for this study. Other unpublished reports related to the issue under study be tried to consult and foreign countries experiences reviewed thoroughly to substantiate the study at hand.

\subsection{Methods of Data Analysis}

Thematic analysis helps in examining and recording patterns with in data. It also helps for giving answers to different research questions. Special emphasis was given to qualitative analysis which helps to understand the causes, challenges and impacts of opposition politics in post 2005 Ethiopian election. Research should be designed, reviewed and undertaken to ensure integrity, quality and transparency. The confidentiality of information supplied by research participants and the anonymity of respondents is respected.

Research participants participated voluntarily, free from any coercion. Harm to research participants was avoided in all instances. The independence of research was clear, and any conflicts of interest or partiality be explicit.

\section{Data Presentation, Analysis, and Discussion}

This part presents the finding of the study. As it is clearly stated in the introduction part (chapter one), the main objective of this study is examining the Politics of Opposition in post -2005 Ethiopia: Challenges and Impacts on Ethiopian Democratic Party (EDP) and Blue Party. The findings are presented and discussed in line with the research objectives. In the process of data presentation, the name of participants is coded (as interviewee 1,2...) for the sake of their security and safeness. Based on the results from the semi-structured interview questions, the findings are summarized and discussed in to two sections. As indicated in the methodology section of this research the researcher intends to collect primary and secondary data through interviews from purposive samples and document reviews. Document review was also another method employed for collecting the required data. From those documents, researches, reports, flyers, publications, broachers were the major ones.

The researcher analyzed and interpreted the data through thematic analysis backed by a brief content analysis as well as discussed the major findings with existing literatures. The emerged themes under challenges are presented in to two. These are internal and external challenges.

\subsection{Internal Challenges of EDP and Blue Parties}

\subsubsection{Weak Party Institutionalization}

The institutionalization of the political parties can be evaluated with respect to organization, discipline, internal democracy, and cohesion [22]. The level of party institutionalization can be also evaluated with the extent to which internal decision procedures are formalized, and to which the party has coordinated structures throughout its 
target constituency [23]. The next dimension is related with the low level of organization and complexity. Opposition parties are not as such territorially comprehensive. They failed to penetrate outside the center. They don't have branches across all regions and most towns of the country. This is because they are relatively new and their activities are focused primarily in the urban areas, but in rural areas, they are less effective in mobilizing public opinion. Interviewee 3 from UDJ explained his experience as follows:

Institutionalized party system help strengthen confidence in the democratic process, it also helps to moderate and to channel societal demands in to an institutionalized environment of conflict resolution, serves to lengthen the time horizons of actors; prevent the dissatisfied groups from resorting to violence; and help to inculcate in the minds of the ordinary people that government is democratically accountable.

But opposition parties in Ethiopia are not well institutionalized; they are in accessible to the mass and rural people this is because of lack of getting committed member ship in rural areas, financial problems, ethnic affiliations' of local people and national opposition parties did not do more activities to attract the attention of the mass. Inadaptability is their failure to be durable opposition parties in general are short-lived and do not have long history and experience. Big weakness of opposition parties is their weak resource capacity, both financial and human resources. As a result, the voters and the mass do not get a chance to evaluate opposition parties' achievements over time.

\subsubsection{Coalition and Fragmentation}

Opposition political parties faced fragmentation as a result of personal party leaders' disagreement, umbrage politics (offensive politics) among members. Intra-party friction also leads to a further fragmentation as the cases of CUD in which EDP was part of the coalition. CUD, disintegrated into many factions due to a leadership problem, the Diaspora Ethiopians' too much interference in the day-to-day activities of the party. Because major opposition parties wasted most of their time fighting each other and were busy in intra-party power struggle. The other factor for fragmentation of parties' decision making is highly centralized. These kinds of parties face split whenever another rising star challenges the founder or the leader of the party [2]. This is one of the reasons for the presence of many, fragmented political parties EDP fragmented from CUD in 2005 and Blue party also exposed to the same problem of fragmentation in 2016. In 2017 after some months of leader ship conflicts Blue party also announced to form coalition with All Ethiopian Unity Organization Party (AEUO). According to interviewee2 from EDP idea of coalition and fragmentation of parties is done easily, he stated his reason as follow as "Coalition and fragmentation of opposition political parties are sudden and unstudied. This is because of lack of objectivity in their establishment, influences from party members and from public i.e. there are public sayings "national opposition parties are either co-op or break up.
Therefore opposition parties at times of coalition they are loosely integrated and easily break up when they face challenges. Interviewee 5 from Blue party explained the ruling parties deliberately employ a "divide-and rule" and the "carrot and stick" policies of the incumbent EPRDF party tactic to fragment and weaken the opposition parties.

But interviewee4 from EPRDF head office suggested that opposition parties by themselves are weak; developed enmities among themselves this is clearly seen when one political leader is replaced by another political leader. Even their coalition is symbolic which can be broken on easy challenges. Interviewee 4 from EPRDF concluded that opposition parties do have internal problems than external. "They do not have clear political goals and objectives, they have short period of alliance that is done only for time of election. On the contrary ruling party is busy in doing its political homework; there is no time of ruling party to follow up and divide acts of oppositions."

Fragmentation complicates coalition-building and inhibits compromise on policy issues. This means a high level of party system fragmentation is detrimental to the proper functioning of democratic regimes. Interview 2 from EDP explained reasons of coalition and fragmentation of opposition parties are in order to solve their financial problems, to get parliamentary seating and fully challenge the ruling party. At the same time they are easily fragmented because their coalition is not done based on principles, care full studying and not from internal feelings of parties rather it is from influences of Diasporas and the public. From interviewees of both opposition and ruling parties fragmentation is a serious challenge seen in opposition political parties.

\subsubsection{Established Around Individual Personalities}

Opposition parties, which usually rely on "the charismatic appeal of single individual" lack structures extending beyond the national executive and decision making is highly centralized and made by few party members and leaders. Most opposition parties in Ethiopia do not have legal restrictions on powers of party leaders. Only the statute of the Ethiopian Democratic Party (EDP) included recently a provision of term limit for the party leader. Political parties often lack standard procedures in candidate nominations and leadership competition. They do not conduct their national assembly meetings regularly and the leadership lacks transparency in the financial administration.

Interviewees 2from EDP, 3 from UDJ and 6 from Blue party forwarded their views on performance of Ethiopian political parties as: Most National opposition political parties in Ethiopia open their office and are active only at time of national elections. Party leaders do not able to train democracy and democratic system of peaceful transition of political power in their time of opposition, rather one person becomes party leader throughout his life time that makes opposition parties similar with the ruling party. The existing political leaders both from the ruling and oppositions are results of the 1960's and 1970's generation that is influenced 
by Marxist- Leninist ideologies. As a result they are running in the political process in the name of democracy. But they do not train democracy in their parties' internal activity.

The researcher looked their policy documents and analyzed election manifestos of these parties EDP Claim different reforms while others claim complete changes in the systems, laws and even the constitution. Interviewees 1 and 5 argue that: "Ruling party's critics on opposition parties are common but meaningless. This is to undermine roles of opposition parties." As the study finding discussed these two parties are at different levels in producing alternative policies. EDP in post 2005 election prepared different alternative policies in the party's manifesto. EDP appreciates some government's policies and actions, with in its "third alternatives." The Blue party's political program and election manifesto claims complete and over all policy changes in the country. According to interviewees 5 and 6 from Blue party, they need over all policy changes because the policies what the ruling government implements are contrary to people and national interest. Therefore, complete policy change is the solution for this country to solve out its social political and economic problems.

\subsubsection{Lack of Political Experience}

Most of the political parties are short-lived and do not have long history and experience. Therefore, the voters do not get a chance to evaluate opposition parties' achievements over time. Parties are formed and fragmented by different names. [24]argues that in Africa, relatively speaking, the only opposition parties that have real chance to compete for power are "movement parties" that emerged from the wombs of the social movements. According to interviewee7 "opposition parties in Ethiopia do not have long history of opposition and experience." In relative term EDP has long political experience in getting representative setting than Blue party. Blue party established in post 2012 and it tried to mobilize young Ethiopian's in different anti-government demonstrations. But both EDP and Blue parties faced the same challenges of fragmentation, intra-party conflict and not able to reach opinions of the mass people. Interviewees 3 and 6 explained that multi-party politics and democracy in Ethiopia has a short history as a result EDP and Blue parties' experiences fragmentation, intra-party conflict, fluctuation of party members and weak political performance.

\subsubsection{Fear of Persecution of Party Members}

Fear of politics on the part of citizens refers to the political apathy and withdrawal from the political process. It is characterized by passive citizenship, the fear of criticism, self-censorship, a fear of contesting authority. Interviewee1 supported this idea: Both EDP and Blue parties faced challenges of low level of membership and mass based support because they fear of persecution from the ruling party and its supporters. According to my interviewee 1 replied that:

In regions of Oromia, Amhara, SNNP and Addis Ababa their large number of party members are highly imprisoned and their party's office is closed. In other regional states EPRDF's affiliated parties do not allow opposition parties to open offices and to mobilize party members. In post 2005 election many opposition party members are either tried to shift their member ship to EPRDF or became politically passive citizens because of fear of persecution and imprisonment.

\subsubsection{Political Parties' Weak Source of Finance}

Political parties finance is the use of funds for legitimate, irregular, or illicit political activities; use of state resources for political purposes; and media coverage during the campaign. According to [25] the main sources of political party funding is coming from public funding and minimal membership fees. They are obliged to have membership registration cards and in some constituencies are expected to participate in the meetings of the party, to express freely their view and comments, to vote and to elect or to be elected. According to the study finding both EDP and Blue parties do not have large number of party members. They faced serious financial challenges to run their own political activities. It is clear that the secret behind the success of every political party is strong financial base. The inequality with the ruling party in this regard is huge. By comparing with the ruling party, interviewees $(2,6$, and 7$)$ and party leaders $(1,3$, and 10) indicated the critical financial situation of opposition parties. They underlined that opposition parties are financially fragile; and there is a chronic shortage of funds needed to finance their operations. Their funding is precarious because of the widespread poverty among the population, the political fear and apathy on their members and supporters. The opposition parties are even unable to pay for office rents. On the contrary ruling party used government and party resources for doing its party role throughout the country. As Johnston (2005, p: 5) said, "Governing parties can tap into 'administrative resources' state powers and funds not available to the opposition which are very useful in rewarding friends and punishing enemies." As the Political finance Proclamations in Ethiopia (Article 28) states, the sources of finance for political parties are membership dues collected from members, subsidy and grants from the government, and donations from others. However, as interviewed parties' leaders remarked, almost every political party relies exclusively on membership fees and donations from party members for funding.

\subsubsection{Lack of Commitment of Party Members}

Party membership refers to the formal and informal membership of political parties. Members identified are those registered who may pay membership dues periodically to the political party in accordance with the by-laws of the political party or they make contributions and donations to upkeep of their parties. As [26] point out 'the strength and vibrancy of parties depends on the quantity and quality of their membership. On the contrary, interviewee2, 7 , and 8 interviewed on the issue of party membership argued that the practical reality in Ethiopian opposition parties is that they 
lack mass membership. They indicated that, in the opposition camp of Ethiopia, among other challenges, membership recruitment and retention is one of the main challenges they face. The status of opposition party membership in Ethiopia does not maintain reliable membership records. In post 2005 elections party members number become declined this is clearly seen in EDP. According to interviewe2 from EDP party members' fluctuation is common to all opposition parties in Ethiopia. Blue party members before 2012 were from the member of All-Ethiopia Unity Organization (AEUO), EDP and former CUD. According to interviewee6 from Blue and 10 from AEUO parties, party member ship fluctuation is because of repressive actions of the existing government on parties and party members. For instance following 2015 national election and 2016 mass based opposition, Blue party and other political party members' imprisonment and desertion increased. As a result getting new party membership and their contributions becomes difficult.

\subsubsection{Absence of Time Limit for Party Leaders}

Political parties often lack standard procedures in candidate nominations and leadership competition. They do not conduct their national assembly meetings regularly. Most opposition parties are highly dominated by founders and leaders. Functioning, preparation for election, merger with other parties, etc are based on the interests of one or few leaders. As a result attempt to change party leaders' leads to shift, fragmentation or formation of new small parties in the country. So far, only the statute of the Ethiopian Democratic Party (EDP) included recently a provision of term limit for the party leader. Blue party faced such challenges when the party's leader has been replaced by the present party's leader. Interviewee 3 and 10 share their experience on this situation as: Party leadership will not be supervised at all by party members and even some opposition political parties like MEDREK and OFC a person once named as president do not want to be replaced by another. Most opposition parties are similar with ruling party in absence of time limit with party leaders. Interviewe3 clearly supported this idea by saying:

Ruling party is by far better than most opposition parties by replacing chairman of the party, though it was natural death (P. M Melese was replaced by Hailemariam). If opposition parties do not able to train democracy through peaceful transfer of power at the time, they will be the same as or harden than the existing ruling party as they are coming to political power. Party leaders tried to mobilize individuals to stay in their party positions than to do parties activities.

\subsubsection{Absence of Ethnic, Religious and Sex Based Representation from Opposition Parties}

According to interviewee $3,6,7$ and 8 Ethnic, religious and sex based representation from national based opposition parties are insignificant. EDP and Blue parties are national opposition parties, but their ethnic, religious and gender representations is the same as other parties. These two parties have different political experiences, EDP has 17 years of political participation in the country while Blue party has 6 years experiences but their ethnic and religious composition makes them be similar. In these two parties there are critics of mass representation. Therefore former politically marginalized women, ethnic and religious groups are not well represented in both EDP and Blue parties. Even largest ethnic groups of Oromo's, the Afar, Somali's, Gumuz, and other minorities are not well represented by EDP and Blue parties. These national parties do their actions by targeting the urban people and the rural populations do not have significant representations.

\subsection{External Challenges of EDP and Blue Parties}

\subsubsection{Political Repression by Government}

The arbitrarily arrest and detention, harassment and torture and other ill-treatment of police, military, and other members of the security forces to punish a spectrum of perceived dissenters, including university students, members of the political opposition and their supporters, and alleged supporters of insurgent groups, as well as alleged terrorist suspects. It also includes systematically repression of failing to provide police and security protection when citizens requested, not allowing them to exercises their right of peaceful demonstration as well as non-inclusion of opposition parties in representative institutions of the country. Interviewees 1, 2, 6 and 8 supported the idea of political repression by government: The ruling party EPRDF has applied different forms of violence against oppositions during and after elections of 2005, 2010 and 2015 such as intimidation, arbitrary arrest and extra judicial killings on opposition party leaders, supporters, private media journalists, bloggers and civil society activists during the complaint investigation process in the post-election periods. This political repression leads people to be hopeless on peaceful means of political struggle. Some groups of people tried to support armed resistance as a means to "liberate the country from EPRDF."

\subsubsection{Inter Party Relations}

The way political parties interact between and among themselves around issues of common interest, and how they work together and engage one another on national and public policy matters. In these relations, the researcher used the term inter-party relations to represent the interrelationships between the ruling party and opposition parties on the one hand, and among opposition parties in the other. Interviewees 2, 3, 5 and 9 forwarded their views on inter party relations as follow as: In Ethiopia, inter-party conflicts not only further fragmented opposition parties, but also greatly damaged their image, and frustrated the hopes of millions of people who overwhelmingly voted them.

In post 2005 national election inter- party relationship is full of machination, disliking and scuttle of one opposition political party against another. Major national opposition parties like EDP, AEUP, MEDREK, Blue party, UJD (Unity for Justice and Democracy) and others are engaged themselves in very destructive inter-party conflicts that threatened their own survival. The ruling party at the same 
time does not want to deal and take positive ideas from opposition parties and to improve existing conditions of the country. At the same time opposition parties are busy in criticizing and opposing every actions of the ruling party. The government and opposition do not see each other as political competitors, but enemies. The researcher during the interview understood thus abnormal/ poor political culture and politics of enmity among opposition parties themselves on one hand and opposition and ruling in the other.

\subsubsection{Political Cleavage Based on Ethnicity}

In the case of Ethiopia, the existing cleavage in the country is mainly ethnicity and ethnic federalism is the basis for organizing the state since the fall of the Derg regime and the coming into power of EPRDF in 1991 [27]. Most political parties have organized themselves along ethno-linguistic lines; the political competition has become unhealthy with an undue focus on identity over actual issues. The non-ethnic national opposition parties faced challenges of mobilizing party members and to do political actions in regional states of Ethiopia. EPRDF that mobilized its supporters by cleverly exploiting ethnicity is a tactic that has immensely helped the ruling party to stay in power for the last two decades. [28] Explained that ethnic belongingness and voters support are highly interrelated. According to my opposition party interviewe 2 and interviewe 5 "the ruling party used ethnicity as a weapon to blackmail and intimidates the non-ethnic opposition parties, this is clearly seen in 2005 election campaign." The incumbent party even accused the CUD and the UEDF of planning to form a Rwandan style "Interahamwe." According to interviewees 6 and in post 2005 the ruling party during elections and political debates tried to soot opposition parties as "reactionaries." The ruling party also allegedly accusing them of being sympathizers of former political order (Hailesilasie and Derg), or being chauvinist or parochialism and for using or tempting to use unconstitutional means to change government, including by establishing ties with outlawed political forces and using popular strikes and they are chauvinistic. Therefore, "if you give your support and voice the former evil will happen again." Since most political parties have organized themselves along Ethno- linguistic lines, the political competition has become unhealthy with all undue focusing on identity rather than on actual issues.

\subsubsection{Weak Political Culture of the People and the Ruling Party}

Political culture is attitudes towards the political system and its various parts, and attitudes towards the role of the self in the system [29]. Political culture also means historically evolved style of governance, a repertoire of power symbolism, and a body of dominant values and commitments regarding the political process [30]. Post-1991 Ethiopia saw significant political institution building and that a public ethos of democracy emerged. But the process is still closely controlled by the ruling EPRDF party. Network of political and economic control was built up by this party from its circle of trusted people, loyalists, and former comrades in the armed struggle [31]. This political culture, engrained in hierarchical authority within the ruling party, has a considerable implication on the role that opposition parties should have to play in the democratic discourse of Ethiopia. Generally, mode of political culture in Ethiopia is marked by an entrenched hierarchical-authoritarian style of governance (top- down) or elite insights into the needs of the country and a structural neglect by power holders of oppositional views and of public opinions. Interviewees 3, 5, 6 and 7 explained Ethiopian political culture as follow as: In Ethiopian history political power is gained through the means of gun. Such violence means of power created a tendency of reliance on force as the principal instrument for political power. Such a tendency of heavy reliance on force caused bloody conflicts among those groups struggling for state power in the history of the country. According to my interviewees such forceful means of securing political power and systematic suppression of political parties contributed for weak democratic political culture of people. On the other hand absence of civic societies in the country, absence of neutral democratic institutions and absence of national consensus among political elites contribute for weak political culture in the country. On the other hand most people like to see political changes in the country, but do not want to invest their time, money and resources on the political process of the country.

\subsubsection{Absence of Neutral Democratic Institutions}

The development of a democratic system of any country is primarily founded on the existence of neutral democratic institutions. Without having such institutions it would be very hard to conduct free, fair, and periodic elections which are essential requirements of modern democracy. The institutional framework of an electoral system is important in maintaining the integrity of electoral outcomes. This in turn helps to maintain credibility and trust on the system. The institutional framework includes the electoral management body and the electoral administration. But according to my informants and some international observers, democratic institutions in Ethiopia are not well established and they are not neutral to serve all parties. For example informants tried to give their arguments on different institutions such as the Ethiopian National Electoral Board. The National Electoral Board of Ethiopia, which is theoretically supposed to be an autonomous and independent body, has been accused of being the mouthpiece of the ruling party. The Board is not strong enough to ensure transparency in its functions. The Board has problems of transparency in allocation of funds to political parties, allocation of air time for campaigning, and post-election complaint handling procedures. According to interviewee 2 and 5 almost all public institutions such as, the security apparatus, media, electoral organs, and administrative structures are under the control of the ruling party in Ethiopia.

On the other hand Medias are not well organized; they are not accessible to the mass and are not neutral. According to interviewees2, 6and 7, absence of independent media outlets, 
it is almost impossible to hold free and fair elections. At the same time, they concluded that it is difficult to find a single independent, non-state affiliated media outlet in Ethiopia today. The majority of newspapers and radio and television stations are state controlled or state affiliated. According to interviewee 2and 3 Medias are busy day and night in magnifying EPRDF's role in the country. Some Diaspora based free Medias, which are transmitted from USA, Europe or other parts of the world to Ethiopia faced systematic repression or can be jammed by the government. Especially after the Anti-Terrorist Proclamation of 2009, independent media have been subjected to intimidation, harassment, can be jammed and in most cases, exile. The military, like other institutions lacks neutrality in the country. The ruling party continuously uses the military for spying, intimidating and arresting opposition party individuals, journalists, bloggers and opposition individuals. Interviewees 2, 3, 5 and 7 concluding that Government intentionally arrested suspected opposition party members, bloggers, journalists and civic organizations who are doing their activities neutrally. The rate of imprisonment is high during and after elections. Thousands of these groups of people are imprisoned following summer, 2016 'mass opposition' from Amhara, Oromia, Addis Ababa, and SNNP.

\subsubsection{Legal and Administrative Measures: Contracting Political Space}

The FDRE constitution contains a vigorous article of political rights which guarantees the right to assembly and the right to organize at any level and in any form, the right to strike in accordance with the law, and the right to express one's opposition [32]. According to key interviewees 2 and 5 the ruling party has not always respected this constitutional arrangement, and the legal system has not been strong enough to enforce these rights and respect for political and democratic rights. At the same time 2009 anti-terrorist law, the country's electoral law and laws related to civil organizations highly restricted opposition political parties and their supporters activity in the country. Opposition political parties also faced challenges from federal and local governments. These two government units in post 2005 election tried to establish different administrative rules and laws which highly restrict parties' activity and contracting political space. According to my interviewees1, 2, 5 agreed on narrow political space in post 2005 national election is clearly seen in areas such as opposition political parties are not allowed to rent offices from private owners, party members are forced to live out of their official works and there are 1 to 5 arrangements which are targeted to evaluate political opinions and positions of civil servants. These legal systems and administrative measures of ruling party affect national opposition political parties not to reach and mobilize people for political change. The Constitution and the Press Law provides for freedom of speech and of the press. However the Government uses legal and other means to limit these rights in practice. As a result people today highly depend on Diaspora based Medias and social Medias.

\subsection{Post 2005 National Election and Its Impact on the Political Atmosphere of the Country, (EDP and Blue Parties) and to the People}

The 2005 National elections mark the first time that voters have witnessed what approximates multiparty competition seem in the country. The disagreement that abruptly flared amongst the ruling party and the major opposition parties regarding the outcome of the elections, that is, the number of votes secured by each one of them in the polls, degenerated into deadly civil disturbances and chaos, resulting in immense destruction of human life and property. Such multiparty competition did not last long in the country's political system. According to interviewees2, 3 and 5 the post 2005 national election and its challenges resulted both positive and negative impacts on Ethiopian political "democratic process." My interviewees 2, 3 and 5 forwarded their experiences on positive and negative impacts of internal and external challenges that faced against opposition parties in post 2005 national election as opposition political parties become more prudent informing coalitions, in framing agendas and alternative policies for voters than the 2005 national election. Many people and parties are aware on ideas of opposition i.e. reasonable support and opposition than the 2005 national election.

Other interviewees 3, 7 and 10 argue that post 2005 national election impact is mostly negative. "It leads people to be hopeless on peaceful struggle, government to be politically more repressive and opposition political parties to be fragmented." Opposition parties become weak, full of conflict of themselves and on the other side ruling party accused them of having a hidden agenda.

This dismantles the opposition block and began to blackmail them to either stop their activities or leave the struggle. According to my interviewees 3 from UDJ and 6 from Blue parties, the 2005 election makes the ruling party to look political issues sensitively, to take out repressive measures against opposition parties and intervene and strictly control of opposition leaders, parties members activities and public demonstrations. Generally the post 2005 national election resulted different challenges to opposition political parties, democratic process of the country and public participation in the political process. Opposition parties become fragmented, engage in intraparty conflicts and party leaders tried to secure personal interest in the name of the party. The 2005 national election was a land mark for Ethiopian political opposition. "People were hopeful in peaceful transmission of political power through election. But post 2005national election resulted in Politics of enmity between Ethiopian political actors." According to interviewee 2 from EDP and 3 from UDJ, the government and opposition do not see each other as political rivals, but as enemies. Subsequently, the elections in Ethiopia have become the source of further animosity and conflicts rather than the expression of the people's will, particularly because the only option in enmity is total victory over another opponent. The researcher also tried to go through analyzing political parties' political program and 
election manifesto. EDP political program claims some revisions in the constitutional and structural revisions. EDP agreed on the existing parliamentary system of government and federal structure of the state. On the other side, Blue party opposition agenda oppose both parliamentary system and existing federal system. Blue party if it is coming in to political power presidential system of government and restructuring of the state will be done. The parliament will be arranged like US senate and congress, the constitution be interpreted by special constitutional court unlike to house of federation. On the contrary ruling party criticized these opposition parties as anti-constitutional, terrorist and enemies of the state. For instance my interviewee 6 from Blue party replied that government considers the name of the party "Blue" as a symbol of rebellion, like the "Orange Revolution" in Ukraine or the failed "Green Movement" in Iran. But according to party's program blue is a symbol of two powerful unifying images for Ethiopians: the 'Blue Nile', and the 'Red Sea'. Government is doubtful on activities and actions of opposition parties. As a result Ethiopian politics becomes abyssal both in the right and in the left sides, which is not suitable to run in the political process. People in case of actively supporting peaceful political process and opposition parties, they are languish for armed struggle and influence of Diaspora's to bring political change in the country. Legal opposition parties are forced to reorganize themselves and to start at the beginning/ from zero in post 2005 national election on wards.

\section{Conclusion and Recommendations}

\subsection{Conclusions}

Based on the previous discussions and findings of the study, the researcher draws the conclusions as per the specific objectives of the study. The study tried to describe on what are challenges that faced against national opposition political parties, this research found from the semi-structured interviewees revealed that Ethiopian national opposition parties do have internal challenges such as: - Weak party institutionalization, Coalition and Fragmentation, Parties establishment around individual personality, failure to Produce alternative Policy, Parties weak sources of finance lack of commitment of party members to their party, Absence of time limit for party leaders, Absence of Ethnic, religious and sex based representation from national based opposition parties. In addition political parties in Ethiopia have also external challenges which affect them not to be functional for their actions. Some of such external challenges affect political parties' activities and people's intentions in the political process include: Political repression of government on opposition parties and party members, Political cleavage based on Ethnicity, Weak political culture of the people and the ruling party, absence of neutral democratic institutions, legal and Administrative Measures contracting political space and absence of free media access to opposition parties. These internal and external challenges of parties according to the research findings have an impact on democratic process of the country. Some of impacts include people to become hope less on peaceful political struggle and opposition political parties in post 2005 national elections. Different violence's have been seen in Oromia, Amhara, SNNP and other parts of the country.

Political enmity between ruling party and oppositions increased from post 2005 national election on wards Political parties' fragmentation, inter and intra party conflict and political violence's increased from time to time in the country. Representatives of Opposition parties in HPR reduced from time to time and become null in 2015 National election.

Generally national and regional opposition parties in Ethiopia do have internal weakness in terms of organization, failure to penetrate their sphere of influence to the mass and not able to shape public political opinions. Opposition parties also do have external challenges from actions of ruling party, institutions and laws of the country.

\subsection{Recommendation}

Based on the findings of the study, the following suggestions were recommended to tackle the identified problems. Parties should maintain some semblance of internal coherence, autonomy, coherence, roots in society and needs to act as a unified organization. Political parties should form programmatic linkages to society and think on how the party voters are attached to them. Opposition parties having similar objectives and programs should form coalition and agglutination: - opposition parties having national stand should adjust themselves in order to lead and shape individualistic and decentralized public political struggles. Opposition parties in case of preaching differences; they should build common national consensus, political values and political cultures which are basic for democratic process of the country is improved. Extreme fragmentation makes them to be weak, inaccessible and fragile. Opposition parties should have roots in the society and open discussions to form coherent and comprehensive policy alternatives. All political parties should come in to national consensus and reconciliation: - both ruling party and oppositions do together for improving common life of the people rather than making conflicts on past. Opposition to opposition and oppositions to incumbent party political discussions and negotiations should be developed. This can reduce political parties' conflicts and improve democratic process of the country. Opposition parties should make suitable condition for the participation of all members in the internal matters of the party.

People should be active participant in the political process of the country: - people's political culture should be developed. They should be ultimate sources of political power of the country by contributing money, knowledge, skills and experiences. People should not expect changes from independent activities of parties by isolating themselves from political process. People should support parties having clear political goals.

The ruling party's political culture towards multiparty 
system and politics of opposition should be improved: intolerant political culture of regime against opposition parties characterized by hierarchic, exclusion and polarization against opposition political parties. The outcome of such polarization can be expected to be the channeling of political opposition through other means than peaceful statements and rallies.

Institutions, the legal and constitutional frameworks should be adjusted to create conducive environment for the development of multiparty politics: - institutions such as election board, Medias, human rights commissions, civil societies and other governmental institutions should be neutral and credible in their functions to serve both opposition parties and the ruling party without any distinction. The country's bureaucracy, army, police, and the judiciary should be non-partisan/ impartial on their acts to the incumbent and opposition parties. If they lack credibility by opposition parties, they can aggravate violence's. Opposition parties should train peaceful transition of political power at time of their opposition: - Political parties often lack standard procedures in candidate nominations and leadership competition. They do not conduct their national assembly meetings regularly and the leadership lacks transparency in the financial administration. Most parties except EDP are highly dominated by founders and leaders. Functioning, preparation for election, merger with other parties, etc are based on the interests of one or few leaders.

Establishment of special institutes for the political education of party members that regularly offers training activities including courses, seminars, special training workshops, analysis and publications are very important for the improvement of performances and efficiency of party members and leaders in the political process as well as improving the political culture of the people.

\section{References}

[1] Schedler, A, (1998). What is Democratic Consolidation? Journal of Democracy, V. 9, Pp 90-105.

[2] Wondwosen Teshome B., \& Jan Záhoík. (2008). "Federalism in Africa: The case of ethnic based federalism in Ethiopia". In: International Journal of Human Sciences, Vol. 5. pp. 1-39.

[3] Lotshwao, K. (2011). The weakness of opposition parties in Botswana: A justification for more internal-party. International Journal of Current Research, 6 (01), Pp. 4798-4799.

[4] Hague; Rod; Martin Harrop and Shaun Bresli. Comparative Government and Politics: An Introduction, 4th edn. Basingstoke: Macmillan.

[5] Institute for Democracy and Electoral Assistance (International IDEA). (IDEA, 2007). As part of its Global Programmed on Research and Dialogue with Political Parties Stockholm.

[6] Assefa. Eshetie. (2002). Ethiopia: Perspectives for Change and Renewal. Boon Keng Road: Lee Press Pvt. Ltd.

[7] Bahru Zewde. (2002). A history of Modern Ethiopia 1855-
1991. Addis Ababa University press.

[8] Andarachew Tiruneh, (1993). The Ethiopian revolution 19741987 A transformation from an aristocratic to a totalitarian autocracy. Cambridge University Press.

[9] Kassahun Berhanu. (2007). Electoral Politics, Decentralized Governance, and Constitutionalism in Ethiopia. (Addis Ababa: Addis Ababa University, pp: 70-88).

[10] Abbink, J. (2006). Discomfiture of Democracy. The 2005 Election Crisis in Ethiopia and Its Aftermath, African Affairs, 105 (419), Pp. 173-199.

[11] Collier, Diamond. (1973). Polyarchy: Participation and Opposition, New Haven: Yale University Press.

[12] GrzymanA-Busse, A. (2003). Political Competition and the Politicization of the State in East Central Europe. Comparative Political Studies, 36 (10), Pp. 1123-1147.

[13] John Ishiyama. (2007). "Nominations and Party Development in Ethiopia: The Opposition and the 2005 Parliamentary Election”. African and Asian Studies, 6 (1-2), Pp. 81-105.

[14] Levitsky andWay. (2002). The rise of competitive authoritarianism. Journal of democracy, 13 (2), Pp. 51-65.

[15] Lyons, T.(2005). Ethiopia: Implications of the May 2005 elections for future democratization Programs, IFES.

[16] Makara, S. (2007). The Challenge of Building Strong Political Parties for Democratic Governance in Uganda: Does multiparty politics have a future? IFRA Les Cahiers (41), 43-80.

[17] Matthias Canton. (2007). Effective Party Assistance: Stronger Parties for Better Democracy. Policy Paper, IDEA.

[18] National Electoral Board of Ethiopia. (2015). NEBE is organizing data for future studies. Retrieved from http://www.electionethiopia.org/en/ Negarit Gazeta. (1993).

[19] Declaration Political Parties Registration Proclamation, Proclamation No. 46/1993, Federal Democratic Republic of Ethiopia (FDRE).

[20] Yohannes Awoke. (2014). The Challenges of Multiparty Democracy in Ethiopia with Particular Emphasis on Electoral Administration. MA thesis, Addis Ababa University.

[21] Vande Walle, N., \& Butler, K. S. (2007). Political parties and party systems in Africa's illiberal democracies. Cambridge Review of International Affairs, 13 (1), 14-28.

[22] Shenton, A. (2004). Strategies for ensuring trustworthiness in qualitative research projects.

[23] Salih, M \& Nordlund, P. (2007). Political Parties in Africa: Challenges for Sustained Multiparty Democracy.

[24] Shedler, A. (2002). The nested game of democratization by elections. International Political Science Review, 23 (1), 103122.

[25] Merera Gudina. (2000). Ethiopia: Competing Ethnic Nationalisms and the Quest for Democracy, 1960. Addis Ababa: Chamber Printing Press.

[26] Lyons, T. (2006) Ethiopia in 2005: The Beginning of a Transition Center for Strategic and International Studies, Africa Notes, 25. 
[27] Julius Kiiza. (2005). A paper presented at the Regional Conference on Political Parties and Democratisation in East Africa. Makerere University, Arusha.

[28] John W. Harbeson. (September, 1996). "Elections and Democratization in Post-Mengistu Ethiopia." Report prepared for the United States Agency for International Development project on Elections in War-Torn Societies. PN-ABZ (710).

[29] HRW Report. (2010). Electoral violence report to UN Security council. Immigration and Nationality Directorate Home Office. Country information and policy unit. United Kingdom.
[30] Gentili, A. M. (2005). Party, party systems and democratization in Sub-Saharan Africa. Paper Presented at the Sixth Global Forum on Reinventing Government, Seoul, Republic of Korea, International Institute for Democracy and Electoral Assistance.

[31] Elischer, S. (2013). Political parties in Africa: Ethnicity and party formation. New York: Cambridge University Press.

[32] Edmond Keller, (June 2002). Ethnic Federalism, Fiscal Reform, Development and Democracy in Ethiopia. African Journal of Political Science (formerly African Journal of Political Economic). 